\title{
Editorial
}

\section{Gerhard Heinzmann}

\section{OpenEdition}

Journals

Édition électronique

URL : http://journals.openedition.org/philosophiascientiae/1230

DOI : 10.4000/philosophiascientiae.1230

ISSN : 1775-4283

\section{Éditeur}

Éditions Kimé

\section{Édition imprimée}

Date de publication : 15 février 2017

Pagination : 3-4

ISBN : 978-2-84174-801-3

ISSN : $1281-2463$

\section{Référence électronique}

Gerhard Heinzmann, « Editorial », Philosophia Scientiæ [En ligne], 21-1 | 2017, mis en ligne le 15 février 2017, consulté le 31 mars 2021. URL : http://journals.openedition.org/philosophiascientiae/1230 ;

DOI : https://doi.org/10.4000/philosophiascientiae.1230 


\section{Editorial}

Gerhard Heinzmann

Laboratoire d'Histoire des Sciences et de Philosophie, Archives H.-Poincaré, Université de Lorraine, CNRS, Nancy (France)

Le premier cahier de Philosophia Scientice est paru il y a plus de vingt ans, en juin 1996. Il a été édité par une jeune équipe des Archives Henri-Poincaré à Nancy et dirigé par le même rédacteur en chef dans un souci constant : promouvoir la recherche en philosophie des sciences, tout particulièrement en ce qui concerne la logique, l'informatique, les mathématiques et la physique, en s'inscrivant dans la tradition analytique, en prenant en compte l'histoire et la pratique des sciences, en préservant le français, l'anglais et l'allemand comme langues « scientifiques» à titre égal.

En passant la main à la nouvelle équipe, Manuel Rebuschi comme rédacteur en chef et Baptiste Mélès comme rédacteur en chef adjoint, j'exprime ma gratitude à Manuel, rédacteur en chef adjoint depuis 2008, et à Sandrine Avril, secrétaire de rédaction, pour leur travail efficace et leur dévouement. Je remercie Madame Charrié des Éditions Kimé, le comité de rédaction et le comité scientifique pour leur coopération facile et collégiale et je suis reconnaissant à l'Université de Lorraine et au CNRS pour leur soutien sans faille.

L'émergence du monde numérique et l'accès en ligne ont changé la dimension de la distribution du savoir et exigent des expertises de plus en plus poussées. Je souhaite à la nouvelle équipe de savoir utiliser ses larges compétences pour saisir l'occasion des nouvelles techniques - tout en conservant les anciennes - afin de consolider l'ancrage national et international de la revue.

The first issue of Philosophia Scientice was published more than twenty years ago in June 1996. It was edited by a young team at the Henri-Poincaré Archives in Nancy and directed by the same editor-in-chief with the same 
constant objective. This was to promote research in philosophy of science, particularly with regard to logic, informatics, mathematics and physics, in line with the analytical tradition and taking into account the history and practice of science. Another aim was to preserve French, English and German as "scientific" languages on an equal basis.

Now I am handing over to the new team-Manuel Rebuschi as editor-inchief and Baptiste Mélès as managing editor. I express my gratitude to Manuel, the managing editor since 2008, and to Sandrine Avril, editorial secretary, for their efficient work done with loyalty. I would also like to thank Madame Charrié of Kimé Editions, the editorial board and the scientific committee for making their cooperation easy and convivial and I am grateful to the University of Lorraine and the CNRS for their unfailing support.

The emergence of the digital world and online access have changed the dimension of the distribution of knowledge and mean more and more expertise is required. My wish for the new team is that they know how to use their broad palette of skills to seize the opportunity offered by new techniques - while preserving the old ones - in order to consolidate the national and international position of the journal.

Gerhard Heinzmann 